\title{
Upwelling characteristics in the Gulf of Finland (Baltic Sea) as revealed by Ferrybox measurements in 2007-2013
}

\author{
Villu Kikas and Urmas Lips \\ Marine Systems Institute at Tallinn University of Technology, Akadeemia tee 15a, 12618 Tallinn, Estonia \\ Correspondence to: Villu Kikas (villu.kikas@msi.ttu.ee)
}

Received: 7 October 2015 - Published in Ocean Sci. Discuss.: 20 November 2015

Revised: 30 May 2016 - Accepted: 9 June 2016 - Published: 1 July 2016

\begin{abstract}
Ferrybox measurements have been carried out between Tallinn and Helsinki in the Gulf of Finland (Baltic Sea) on a regular basis since 1997 . The system measures autonomously water temperature, salinity, chlorophyll $a$ fluorescence and turbidity and takes water samples for further analyses at a predefined time interval. We aimed to show how the Ferrybox technology could be used to study the coastal upwelling events in the Gulf of Finland. Based on the introduced upwelling index and related criteria, 33 coastal upwelling events were identified in May-September 20072013. The number of events, as well as the frequency of their occurrence and intensity expressed as a sum of daily average temperature deviations in the $20 \mathrm{~km}$ wide coastal area, were almost equal near the northern and southern coasts. Nevertheless, the wind impulse, which was needed to generate upwelling events of similar intensity, differed between the northern and southern coastal areas. It is suggested that the general thermohaline structure adapted to the prevailing forcing and the estuarine character of the basin weaken the upwelling created by the westerly to southwesterly (up-estuary) winds and strengthen the upwelling created by the easterly to northeasterly (down-estuary) winds. Two types of upwelling events were identified - one characterized by a strong temperature front and the other revealing gradual decrease in temperature from the open sea to the coastal area, with maximum temperature deviation close to the shore.
\end{abstract}

\section{Introduction}

Unattended monitoring of marine environments using ships of opportunity has been implemented in many regions of the world ocean (e.g., Paerl et al., 2009; Hardman-Mountford et al., 2008), including the Baltic Sea and the Gulf of Finland (Rantajärvi, 2003). The measurement systems installed on board commercial ferries or other ships are called "Ferryboxes", and they consist of various sensors, devices creating water flow through the sensors and software packages controlling the system and managing the data. The commonly used Ferryboxes measure temperature, salinity, and chlorophyll $a$ fluorescence in the seawater pumped through the system from the surface layer along the ship track. First trials of using ships of opportunity for environmental monitoring in the Gulf of Finland were made by Estonian and Finnish scientists between Tallinn and Helsinki in 1990 1991 (Rantajärvi, 2003). Regular Ferrybox measurements along this route were started in 1997, while the longest data series of Ferrybox measurements (since 1993) is available along the Helsinki-Travemünde ferry route (Petersen, 2014).

The Gulf of Finland (GoF) lies in the northeastern part of the Baltic Sea (Fig. 1). It is an elongated basin with a length of about $400 \mathrm{~km}$ and a maximum width of $135 \mathrm{~km}$ (Alenius et al., 1998). The vertical stratification in the gulf is characterized by a quasi-permanent halocline at a depth of $60-80 \mathrm{~m}$, and a seasonal thermocline, which forms in spring-summer at a depth of 10-20 m (e.g., Liblik and Lips, 2011). The longterm residual circulation in the surface layer of the gulf is characterized by a relatively low speed and by a cyclonic pattern. The saltier water of the northern Baltic proper flows into the gulf along the Estonian (southern) coast, and the gulf water, which is less saline due to the large freshwater inflow at the eastern end of the gulf (the Neva River), flows out along the Finnish (northern) coast. The circulation is more complex at timescales from days to weeks mainly due to the variable wind forcing. A variety of mesoscale processes/features (fronts, eddies, coastal upwelling/downwelling), which sig- 

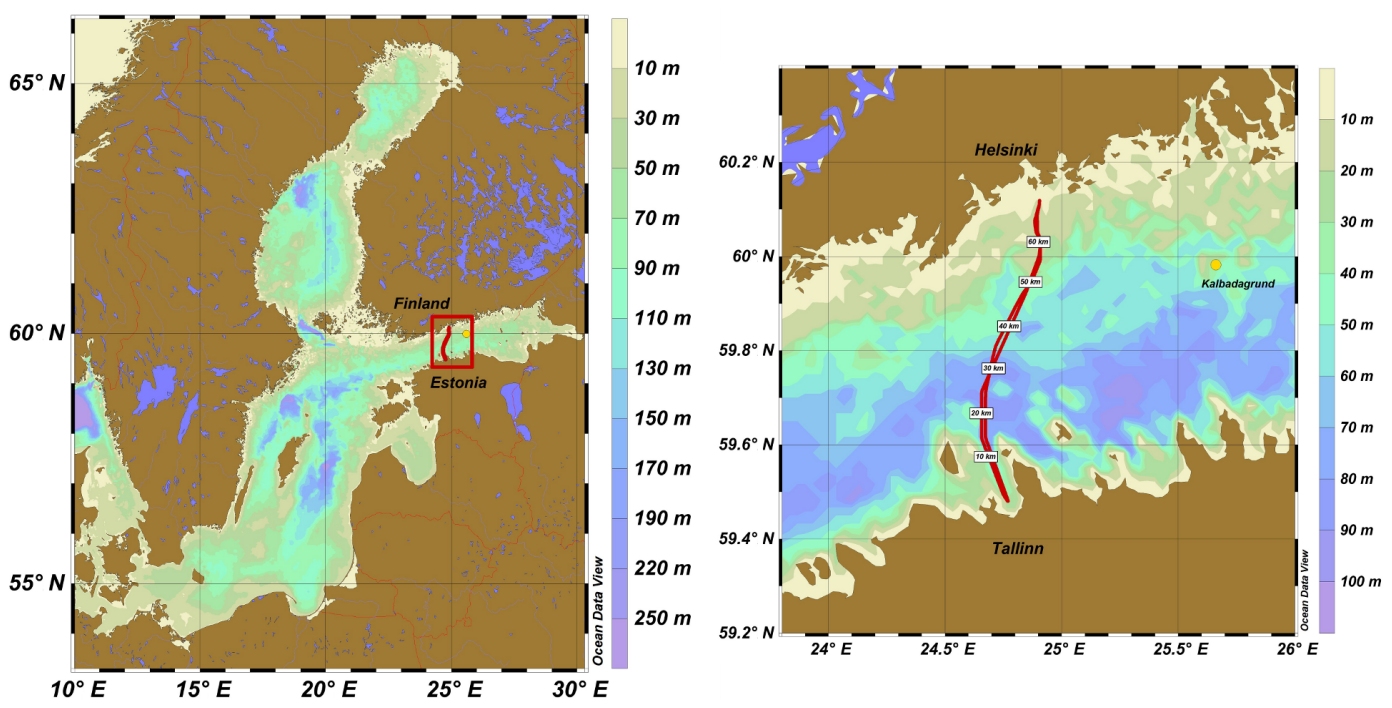

Figure 1. Map of the Baltic Sea (a) and the study area (b) with the Ferrybox transect and Kalbadagrund meteorological station. Maps are made using Ocean Data View software (Schlitzer, 2015).

nificantly affect the biological production, retention, and transport, have been observed in the Gulf of Finland (e.g., Talpsepp et al., 1994; Kononen et al., 1996; Pavelson et al., 1997; Vahtera et al., 2005; Lips et al., 2009).

Dynamics and characteristics of upwelling events have been studied in the Gulf of Finland based on in situ measurements (e.g., Haapala, 1994), remote sensing (e.g., Uiboupin and Laanemets, 2009) and modeling (e.g., Myrberg and Andrejev, 2003). Most prominent upwelling events that were captured by measurements are an event along the northern coast in July 1999 (Vahtera et al., 2005) and an event along the southern coast in August 2006 (Lips et al., 2009). The following characteristic features of upwelling events in the Gulf of Finland are suggested:

1. the Finnish coastal sea in the northwestern GoF is one of the main upwelling areas in the Baltic Sea (Myrberg and Andrejev, 2003), where upwelling frequency in MaySeptember 1990-2009 has been up to 15\% (Lehmann et al., 2012); almost the same upwelling frequency is suggested by the latter authors for the central GoF along the Estonian (southern) coast;

2. mean upwelling area detected on the basis of 147 maps during the period of 2000-2009 was $5642 \mathrm{~km}^{2}$ (19\% of the GoF surface area) along the northern coast and $3917 \mathrm{~km}^{2}$ (13\% of the GoF surface area) along the southern coast (Uiboupin and Laanemets, 2015), while the largest area covered by the upwelling water was identified as $12140 \mathrm{~km}^{2}$ (data from 2000 to 2006; Uiboupin and Laanemets, 2009); the authors' estimate of the mean cross-shore extent of the upwelling area was $20-30 \mathrm{~km}$ off the northern coast and varied between 7 and $20 \mathrm{~km}$ off the southern coast;
3. the intensity of upwelling events depends on the values of cumulative upwelling-favorable wind stress and strength of vertical stratification; Haapala (1994) suggested that an at least $60 \mathrm{~h}$ long wind event has to exist to create an upwelling event; based on the wind data analysis from 2000 to 2005 and taking the threshold value for cumulative wind stress of $0.1 \mathrm{~N} \mathrm{~m}^{-2}$ day, on average, about two upwelling events should appear off the southern coast and four events off the northern coast (Uiboupin and Laanemets, 2009);

4. it is suggested that the difference in topography off the southern and northern coasts of the GoF results in differing upwelling dynamics along the opposite coasts in the case of similar wind stress (but in opposite directions) the transport of waters from deeper layers starts earlier and is larger along the southern coast (Väli et al., 2011).

The motivation of the present paper is to show how the Ferrybox technology can be used to study mesoscale processes, especially coastal upwelling events in the Gulf of Finland. We describe the approach, its advantages and limits, and present statistical characteristics of upwelling events on the basis of data collected in 2007-2013. The main aims are to relate the observed variability and dynamics of upwelling events to the atmospheric forcing, to reveal the differences in upwelling behavior in the northern and southern coastal areas, and to suggest an alternative physical explanation of the found differences by taking into account the prevailing forcing and estuarine character of the basin. 


\section{The measurement system and methods}

\subsection{Ferrybox system}

Temperature $(T)$, salinity $(S)$, chlorophyll $a$ fluorescence and turbidity data and water samples for nutrients and phytoplankton chlorophyll $a(\mathrm{Chl} a)$, species composition and biomass analyses have been collected unattended on passenger ferries traveling between Tallinn and Helsinki (Fig. 1) since 1997. Due to the internal arrangements of ferry company Tallink Silja and its predecessors, several ships were used as the platforms for Ferrybox measurements, which also differ regarding water intake features. A flow-through system from $4 \mathrm{H}-J e n a$, Germany, with the water intake attached to the sea chest of the ferry, has been in use since 2006. The water enters the sea chest through a grating with a total surface area of $0.84 \mathrm{~m}^{2}$ located at about $4 \mathrm{~m}$ depth below the waterline. The water flow from the sea chest into the system is forced by the hydrostatic pressure since the Ferrybox is located on the lower deck about $3 \mathrm{~m}$ below the waterline. To restrict larger particles from getting into the measurement system, a mud filter (pore size $1 \mathrm{~mm}$ ) is used close to the water intake. Before the sensors, a debubbler is installed to avoid air bubbles to affect the measurements of conductivity, turbidity and $\mathrm{Chl} a$ fluorescence. The flow rate through the sensors is stabilized by an internal pump, which is controlled by a pressure sensor in the system. Water samples are taken by a sampling device (Hach Sigma 900 MAX), whereas the water is pumped from the debubbler into the bottles using an internal pump of the water sampler.

For temperature measurements, a PT100 temperature sensor is used that is installed close to the water intake to diminish the effect of warming of water while flowing through the tubes onboard. The sensor has a measuring range from -2 to $+40^{\circ} \mathrm{C}$ and an accuracy of $\pm 0.1 \%$ of the range, i.e., $0.04{ }^{\circ} \mathrm{C}$. For salinity measurements an FSI Excell thermosalinograph (temperature and conductivity meter) and for Chl $a$ fluorescence and turbidity measurements a SCUFA submersible fluorometer (Turner Designs) with a flow-through cap are used. The accuracy of the conductivity sensor is $0.0025 \mathrm{~S} \mathrm{~m}^{-1}$. The system starts the measurements and data recording when the ferry is away from the harbor more than a predefined distance of 0.7 nautical miles (controlled by a GPS device in the system) and stops when it is closer than this distance to avoid sediments getting into the system. The data are recorded during every crossing (twice a day) every $20 \mathrm{~s}$, which corresponds to a horizontal resolution of approximately $160 \mathrm{~m}$.

\subsection{Quality assurance and pre-processing of data}

The sensors have been calibrated at the factory before the installation and if necessary sent for an additional laboratory calibration. Since the system contains two temperature sensors, the performance of them is routinely followed by a comparison of data acquired from the sensors. The quality of thermosalinograph data is guaranteed by taking a series of water samples (14-17 samples) and analyzing them using a high-precision salinometer (AUTOSAL) two to four times a year. The analyses have shown that a correction of 0.08 (units in Practical Salinity Scale; the value has been stable over the years) must be added to the recorded salinity. While the raw salinity is recorded in units according to the Practical Salinity Scale 1978, the results on salinity distribution and variability are given in the paper (Sects. 3 and 4) in $\mathrm{g} \mathrm{kg}^{-1}$ according to Feistel et al. (2010). Particular care is taken to calibrate the SCUFA fluorometer; however, since we do not use the fluorometer data in this study, the used routine is not described here.

The data acquired by the Ferrybox system recorded with a time step of $20 \mathrm{~s}$ are stored in an onboard terminal. To synchronize the measurements performed by the sensors with different sampling frequencies and GPS, the acquired data within every $19 \mathrm{~s}$ interval are averaged and recorded as measurements at every 20th second. The data are automatically delivered to the on-shore FTP server once a day when the ferry is in the harbor using a GSM connection. The performance of the system is validated by the control parameters, such as the flow rate and pressure in the system, and the data are checked for unrealistic values against the criteria set for every parameter on the basis of known natural variations of them in the Gulf of Finland.

One of the procedures, which has to be carried out when using the Ferrybox data, is the shifting of data points to the actual positions of the water intake. The problem arises since the coordinates attached to a data record correspond to the location of the ferry at the time of measurement, but the water is taken in earlier at a different position. Since various systems of water intake are applied, this procedure is unique for each combination of a Ferrybox and a ferry. As described above, in our design the seawater enters first a relatively large sea chest and the flushing through-time of it is unknown. While the water flows through the sea chest and into the tubes and debubbler with a flow rate of $12-15 \mathrm{~L} \mathrm{~min}^{-1}$, the ferry moves on at an average speed of 16 knots. We solved the problem of position correction taking into account the advantage of having two crossings a day.

Analysis of data from return journeys allowed us to introduce a position correction procedure - the best result is achieved by shifting the measured data points against the GPS time for 3-4 min, depending on the ferry and exact intake installation. This relatively long period is obviously related to the water exchange in the sea chest. Due to an almost constant cruising speed of the ferry outside the harbor areas, the applied procedure gives acceptable results. The comparison of data from Tallinn to Helsinki and back from Helsinki to Tallinn obtained on the same day is one of the used quality assurance procedures - the profiles containing unexpected deviations are marked by a quality flag indicating a possible quality problem. 


\subsection{Data and calculation methods}

Temperature and salinity data collected along the TallinnHelsinki ferry line from May to September in 2007-2013 are used for analysis purposes. In 2008, the system on board the passenger ferry "Galaxy" was in use until 13 July and the measurements started again on 13 August when the system was installed on board the ferry "Baltic Princess". However, due to some technical problems, the regular measurements were only reliable from 2 September 2008. A failure of the system occurred late August 2012 and, therefore, the data are not available from 29 August until the end of September 2012. In early 2013, the next ferry ("Silja Europa") came to this line and the system was moved again, causing a break in the measurements until 15 July 2013. The number of crossings with the full data coverage is given in Table 1. Four years - 2007, 2009, 2010 and 2011 - were the years with almost complete data coverage, while most of the data were not available in the second half of July and August 2008, in September 2012 and in May, June and the first half of July 2013. Thus, the data from all months from May to September were analyzed at least from 6 years in 20072013.

Collected raw data were preliminarily processed, including shifting of measurements as described in Sect. 2.2, quality checked and stored in the database. This data set was used to draw the maps of temporal variations of horizontal distributions of $T$ and $S$ for all studied years (Fig. 2). A step (cell width) of $0.5 \mathrm{~km}$ along the south-north oriented line was used to transform the data set from the matrix with a constant time step into the matrix with a constant spatial resolution. The fixed south-north orientation was applied to eliminate the influence of differences in orientation of the ship track in the southern, central and northern parts of the route (see Fig. 1) and of possible deviations from the usual route. As a result, the extent of the upwelling area is presented below in the south-north direction, and a coefficient has to be applied to convert these values to the upwelling extent in the cross-shore direction (as the cosine of the angle between the south-north direction and a perpendicular line to the shore approximately $20^{\circ}$ ).

An upwelling index was introduced in the coastal area off the southern coast $\left(\mathrm{UI}_{\mathrm{S}}\right)$ and off the northern coast $\left(\mathrm{UI}_{\mathrm{N}}\right)$. For each crossing, the average water temperature and horizontal profile of temperature deviations from the average were computed. The upwelling index was calculated as a sum of negative temperature deviations in the coastal areas $(0-20 \mathrm{~km}$ offshore) as

$\mathrm{UI}_{\mathrm{S}}=\sum_{\Delta T_{i}<0}^{i=1 \ldots 40}\left|\Delta T_{i}\right|$ and $\mathrm{UI}_{\mathrm{N}}=\sum_{\Delta T_{i}<0}^{i=101 \ldots 140}\left|\Delta T_{i}\right|$,

where $\Delta T_{i}$ is the temperature deviation of $0.5 \mathrm{~km}$ cell $i$ from the average temperature of the crossing. The width of $20 \mathrm{~km}$ was selected on the basis of the analysis of all available tem- perature data from the Tallinn-Helsinki ferry line in 20072013 (see Sect. 3.1 for details). The daily indexes were obtained by averaging the two upwelling indexes from a single day (from a return journey of the ferry). A cumulative upwelling index (CUI) can be calculated by summing up upwelling index values for certain periods. The obtained CUI values were divided by 40 , which is the number of data cells in the $20 \mathrm{~km}$ wide coastal area, to keep the meaning of CUI as the sum of average negative temperature deviations, having a unit of ${ }^{\circ} \mathrm{C}$ day:

$\operatorname{CUI}_{\mathrm{S}}(n 1 \ldots n 2)=\sum_{j=n 1}^{j=n 2}\left(\frac{1}{40} \mathrm{UI}_{\mathrm{S} j}\right)$
and $\mathrm{CUI}_{\mathrm{N}}(n 1 \ldots n 2)=\sum_{j=n 1}^{j=n 2}\left(\frac{1}{40} \mathrm{UI}_{\mathrm{N} j}\right)$,

where $n 1$ and $n 2$ are the start and end day numbers of the selected period, for which the cumulative upwelling index is calculated, and $\mathrm{UI}_{\mathrm{S} j}$ and $\mathrm{UI}_{\mathrm{N} j}$ are the upwelling indexes at day $j$ off the southern and northern coasts, respectively. This approach of the CUI calculation is similar to that used previously in the studies of upwelling events and their influence on the phytoplankton dynamics in the Gulf of Finland (see, e.g., Lips and Lips, 2008; Myrberg et al., 2008).

An upwelling event can be characterized by the cumulative upwelling index calculated for the period when the upwelling index $\left(\mathrm{UI}_{\mathrm{N}}\right.$ or $\mathrm{UI}_{\mathrm{S}}$ ) exceeded a certain threshold value. We have defined this threshold value as $40^{\circ} \mathrm{C}$, which corresponds, e.g., to a $20 \mathrm{~km}$ wide upwelling with an average negative temperature deviation of $1{ }^{\circ} \mathrm{C}$. This choice is explained in more detail in Sect. 3.2.

Wind data were obtained from the HIRLAM (HighResolution Limited Area Model) version of the Estonian Meteorological and Hydrological Institute with the spatial resolution of $11 \mathrm{~km}$ and the time interval of $3 \mathrm{~h}$ (Väli, 2011; Männik and Merilain, 2007). The model data point close to Kalbådagrund, where a meteorological weather station is also located (Finnish Meteorological Institute), was chosen to represent the wind conditions in the study area. The data from Kalbådagrund weather station or the closest HIRLAM model point have also been used in the earlier studies of coastal upwellings in the Gulf of Finland (Lips et al., 2008a; Uiboupin and Laanemets, 2009). According to Keevallik and Soomere (2010), the HIRLAM output matches well with the observations at Kalbådagrund (the wind is measured at $32 \mathrm{~m}$ ), although the modeled wind direction (at $10 \mathrm{~m}$ height) is turned $20^{\circ}$ counter-clockwise from the measured wind direction.

Wind stress (in $\mathrm{N} \mathrm{m}^{-2}$ ) is calculated for the wind component along the axis of the Gulf of Finland, which corresponds to the direction turned by $70^{\circ}$ clockwise from the northerly direction, as

$\tau_{70}=C_{\mathrm{D}} \rho_{\mathrm{a}}|U| U_{70}$, 
Table 1. Periods of measurements along the Tallinn-Helsinki ferry route in 2007-2013, number of days with measurements and number of days with upwelling events off the northern coast $(\mathrm{N})$ and off the southern coast $(\mathrm{S})$.

\begin{tabular}{lllrrr}
\hline Year & Ferry & Period & $\begin{array}{r}\text { Number of } \\
\text { days with data }\end{array}$ & \multicolumn{2}{c}{$\begin{array}{c}\text { Number of days } \\
\text { with upwelling }\end{array}$} \\
\cline { 5 - 6 } & & & $\mathrm{N}$ & $\mathrm{S}$ \\
\hline 2007 & Galaxy & 1 May-30 September & 141 & 26 & 21 \\
2008 & Galaxy & 1 May-13 July & 90 & 8 & 11 \\
& Baltic Princess & 13 August-30 September & & & \\
2009 & Baltic Princess & 1 May-30 September & 145 & 33 & 30 \\
2010 & Baltic Princess & 1 May-30 September & 140 & 5 & 32 \\
2011 & Baltic Princess & 1 May-30 September & 135 & 19 & 30 \\
2012 & Baltic Princess & 1 May-28 August & 113 & 22 & 0 \\
2013 & Silja Europa & 15 July-30 September & 74 & 37 & 16 \\
\hline
\end{tabular}

where $U$ is the wind speed (in m s${ }^{-1}$ ), $U_{70}$ is its component in the along-gulf direction, $C_{\mathrm{D}}$ is the drag coefficient (a constant value of $1.2 \times 10^{-3}$ was chosen in the present study; Large and Pond, 1981), and $\rho_{\mathrm{a}}$ is the air density $\left(1.2 \mathrm{~kg} \mathrm{~m}^{-3}\right)$. Accordingly, positive values of the wind stress should initiate southward Ekman transport in the surface layer and vice versa. The cumulative wind stress (in $\mathrm{N} \mathrm{m}^{-2}$ day) was calculated based on daily averages of wind stress. If the cumulative wind stress is large enough, upwelling events occur along the northern coast in the case of the positive wind stress and along the southern coast in the case of the negative wind stress.

\section{Results}

\subsection{General variability and distribution patterns}

The typical seasonal course of the surface layer temperature in the Gulf of Finland is characterized by temperatures of about $5{ }^{\circ} \mathrm{C}$ at the beginning of May, a maximum of $>20^{\circ} \mathrm{C}$ in late July-early August and a drop below $15^{\circ} \mathrm{C}$ in late September. Within the analyzed years 2007-2013, the surface layer temperature was highest in summer 2010 (Fig. 2) when the period with the average along-transect temperature of $>20^{\circ} \mathrm{C}$ was 35 days. Against the background of seasonal course and simultaneous shorter-term increases or decreases in temperature over the whole study transect, periods with distinctly lower temperature were observed off the northern or southern shore. Such situations are related to the coastal upwelling events - their characteristic timescale was several days to 1-2 weeks, and they extended towards the open sea by $15-20 \mathrm{~km}$ (Fig. 2).

Interannual variations of the surface layer salinity in 20072013 were high, with the highest salinity in 2011 and the lowest in 2009. The surface layer salinity exceeded $6.5 \mathrm{~g} \mathrm{~kg}^{-1}$ for a longer period only in 2011 in the southern half of the study transect (Fig. 2j) and for shorter periods of several days in the case of coastal upwelling events off the southern shore (e.g., Fig. 2b and d). Note that in the case of coastal upwelling events seen in the temperature distributions off the northern coast, a simultaneous increase in salinity was not very visible. As a rule, the surface layer salinity was higher near the southern coast than that near the northern coast. However, often the lowest salinity was measured in the middle of the transect - that is, in the open sea areas (e.g., Fig. $2 f$ and $h$ ). The seasonal course of salinity differed remarkably between the years. While usually the lowest surface layer salinity was observed in June-July, in 2008 the salinity was lowest in May, and in 2010 and 2011 it was lowest in August.

The average temperature and salinity deviations in MaySeptember each year and for the entire study period, as well as their root mean square errors (RMSEs), were calculated in each $0.5 \mathrm{~km}$ cell. On average, the temperature deviations were close to zero along the entire study transect (Fig. 3a) - the absolute values of average deviation were 6 times less than the estimated RMSE of temperature. Nevertheless, the surface layer temperature was slightly warmer in the open Gulf of Finland than in approximately $20 \mathrm{~km}$ wide coastal areas (Fig. 3a). We relate this finding to the occurrence of coastal upwelling events. For instance, in 2009, when coastal upwelling events were observed off both coasts, the average temperature deviations were negative near both coasts (Fig. 3c). In 2010, when upwelling events occurred mostly off the southern coast, the negative values of average temperature deviations were detected only in the southern part of the transect (Fig. 3e).

It is remarkable that, on average, the variability of temperature deviations was much higher near the coasts than in the central part of the study transect (Fig. 3a). In the case of upwelling events off the southern coast and their absence off the northern coast (in 2010), this high variability of temperature was concentrated only in the $20 \mathrm{~km}$ wide coastal area off the southern shore (Fig. 3e). We suggest that this high variability of temperature in the coastal areas is mostly related to the upwelling activity and, therefore, we estimated the intensity of 

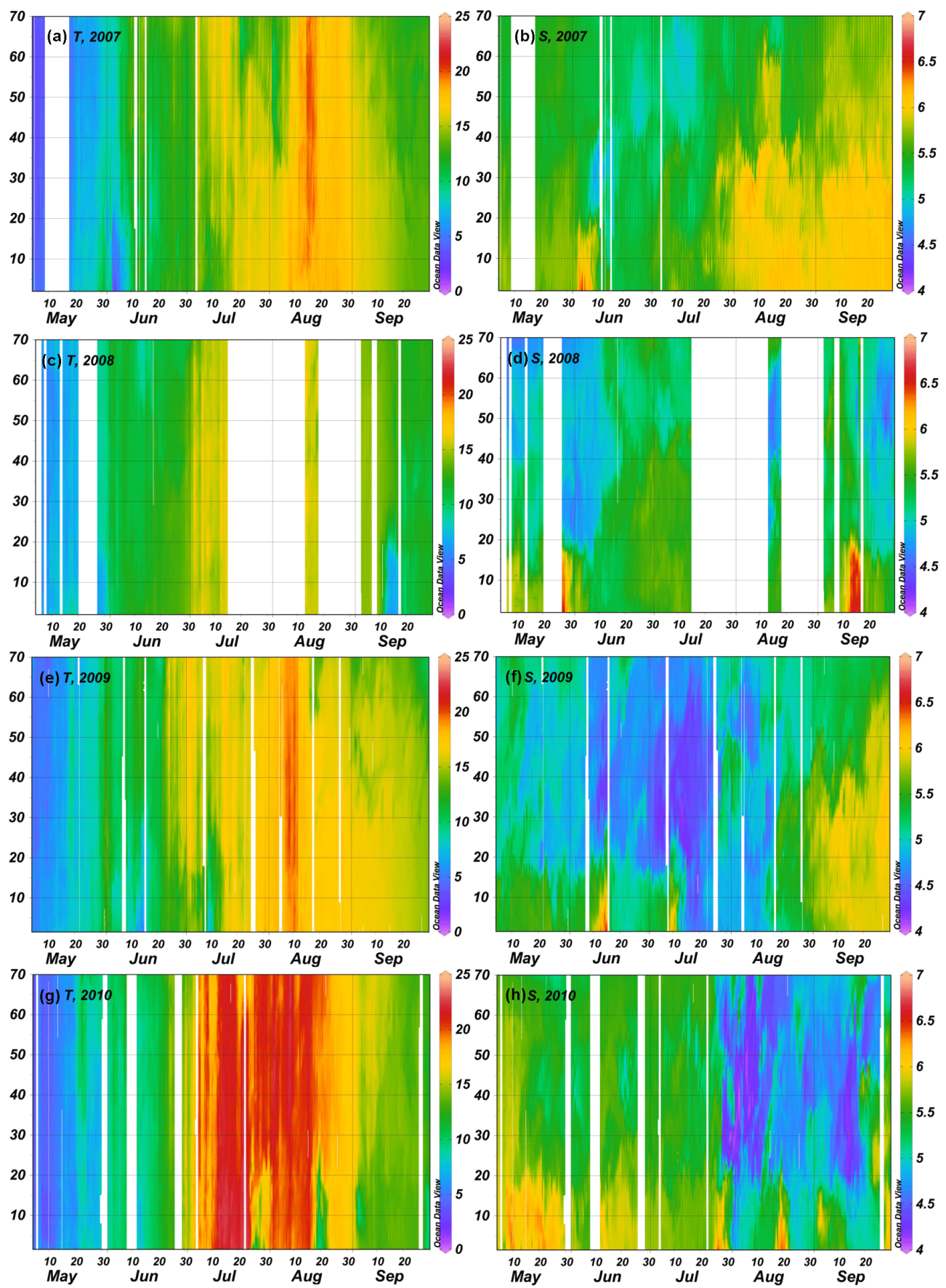

Figure 2.

upwelling events based on data from the $20 \mathrm{~km}$ wide coastal zones.

The average distribution of the surface layer salinity along the transect was characterized by higher salinity values in the southern gulf and lower values in the northern gulf (Fig. 3b). The salinity deviations were positive in the $28 \mathrm{~km}$ wide area off the southern coast (with clearly higher salinity in the first $10 \mathrm{~km}$ ) and negative along the rest of the study transect. How- ever, the minimum of the surface layer salinity was observed at about $20 \mathrm{~km}$ from the northern shore (or at a distance of $50 \mathrm{~km}$ from the southern end of the study transect) in almost every year (Fig. 3b, d, and f). The only exception was the year 2007 when the lowest salinity was observed on average in the cell closest to the northern shore. The low salinity water at the distance of $50 \mathrm{~km}$ indicates that, in summer, the outflow of the less saline Gulf of Finland surface waters oc- 

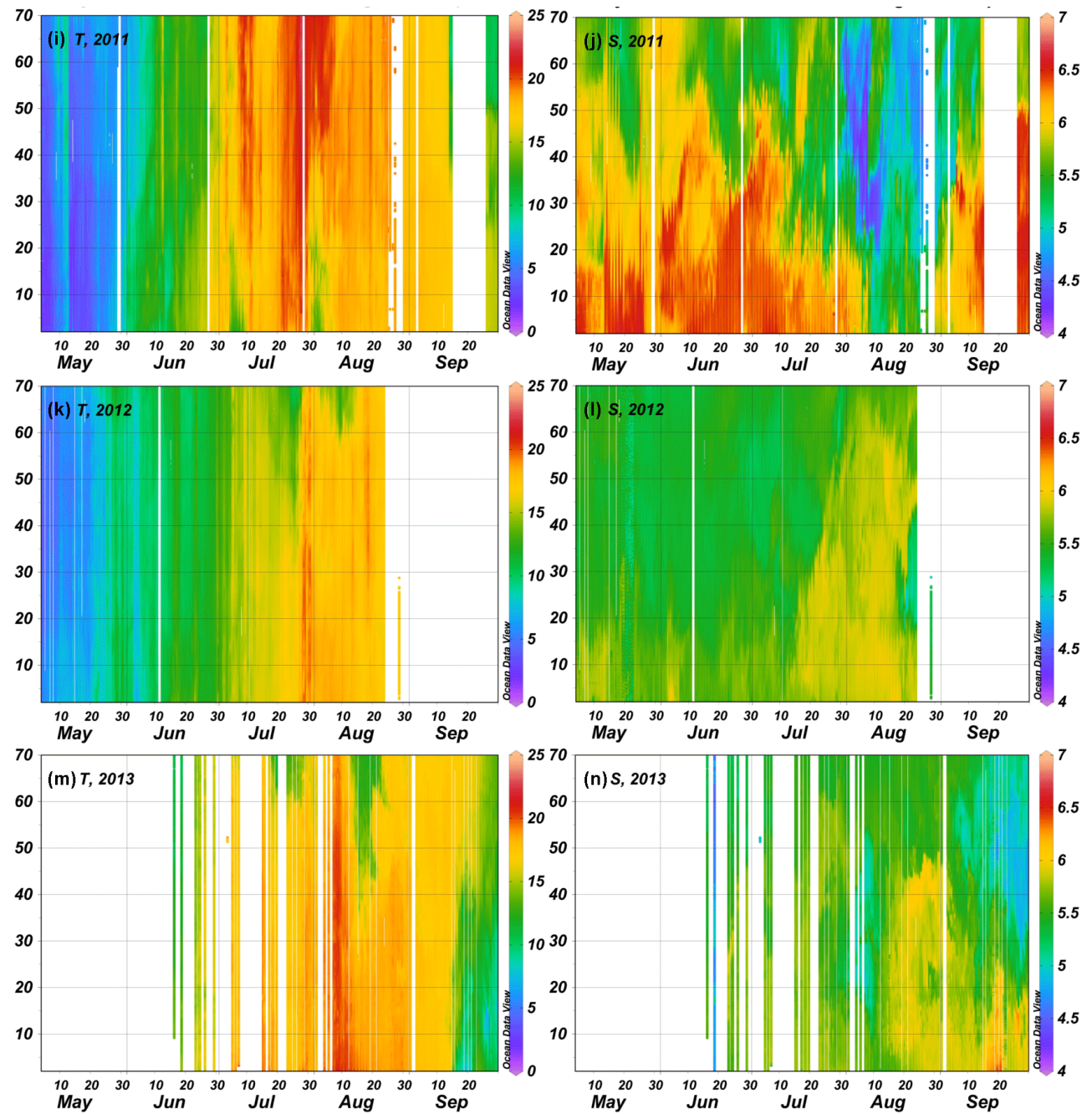

Figure 2. Temporal changes in temperature (in ${ }^{\circ} \mathrm{C}$ ) and salinity (in $\mathrm{g} \mathrm{kg}^{-1}$ ) distributions between Tallinn and Helsinki from $1 \mathrm{May}$ to 30 September in 2007 (a, b), 2008 (c, d), 2009, (e, f), 2010 (g, h), 2011 (i, j), 2012 (k, l) and 2013 (m, n); $y$ axis shows the distance from Tallinn Bay (latitude 59.48 N) in km along the meridional transect. Maps are made using Ocean Data View software (Schlitzer, 2015).

curs mostly in the northern part of the open gulf. The variability of the surface layer salinity did not differ between the coastal and open sea areas as much as the variability of the surface layer temperature. One can recognize slightly higher variability (RMSE) of the surface layer salinity in the coastal areas and the southern part of the open gulf at a distance of $20-30 \mathrm{~km}$.

\subsection{Upwelling characteristics}

As is seen on the maps of temperature deviations (Fig. 4), the years 2007 and 2009 had a similar pattern - the upwelling events occurred off the southern coast in the first half of the season and off the northern coast in the second half. In 2008, upwelling events were observed near the southern coast in May and September, and they appeared near the northern coast in June. The year 2010 was an exceptional year when the upwelling events occurred mostly along the southern coast. It was exceptional also because the sea surface temperature outside the upwelling waters was the highest among the studied summers. A sequence of consecutive upwelling events near the northern and southern coasts was observed in 2011. Upwelling events occurred mostly off the northern coast in 2012 and 2013.

We selected a criterion to detect whether an upwelling event occurs or not as the value of the upwelling index (UI) exceeded $40^{\circ} \mathrm{C}$ (in absolute values, while UI is by definition a negative number). The upwelling events found using the selected criterion were also the occasions when the maximum negative temperature deviation from the transect mean value was at least $-2{ }^{\circ} \mathrm{C}$ (except one event on 10-17 September 2007 when the maximum deviation was $-1.97^{\circ} \mathrm{C}$ ). Furthermore, no other cases with negative temperature deviations exceeding $-2{ }^{\circ} \mathrm{C}$ were detected. Thus, the criterion UI 

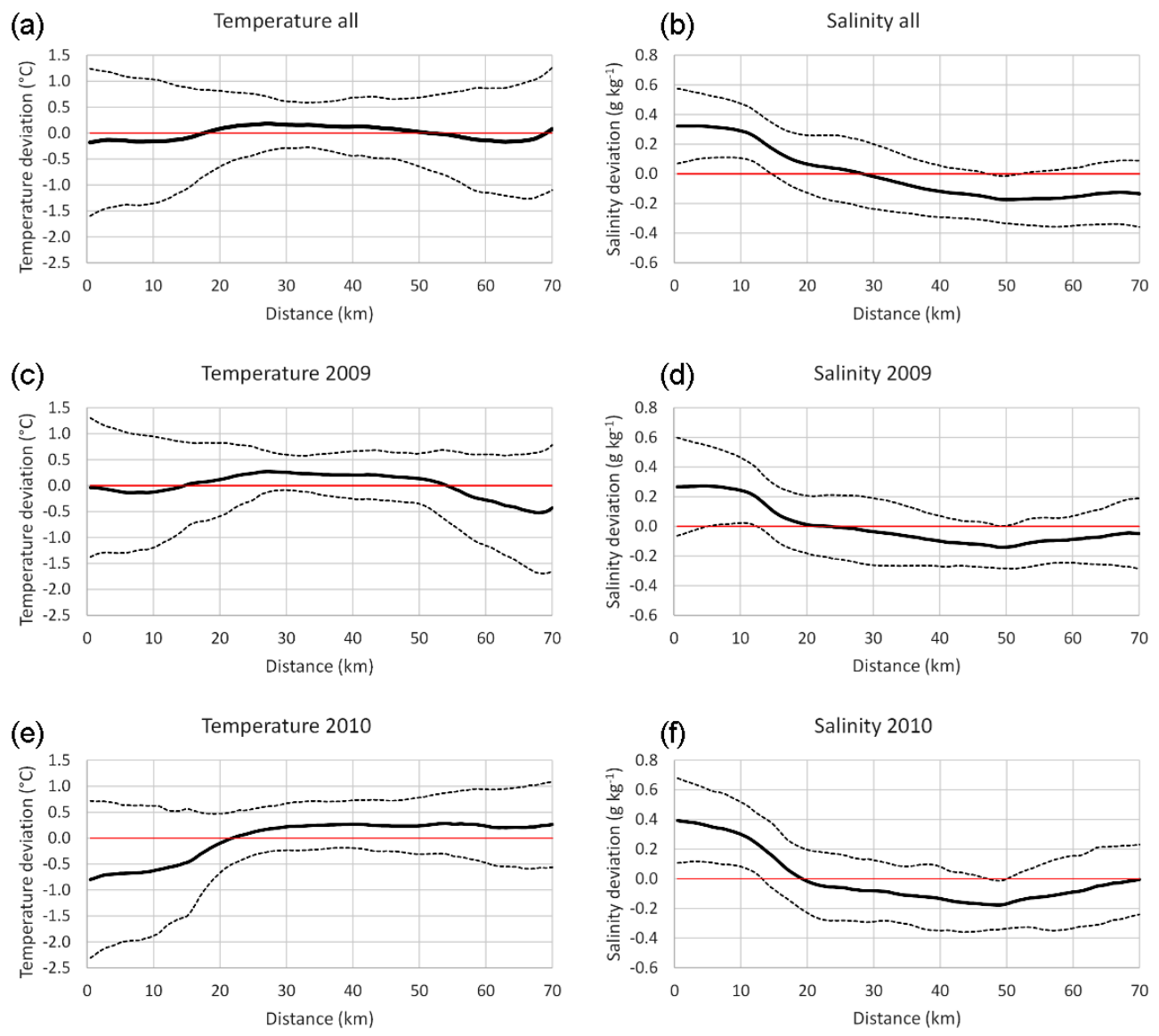

Figure 3. Distributions of temperature (in ${ }^{\circ} \mathrm{C}$ ) and salinity (in $\mathrm{g} \mathrm{kg}^{-1}$ ) deviations from the transect mean value along the Tallinn-Helsinki ferry route for all measurements in May-September 2007-2013 (a, b), 2009 (c, d) and 2010 (e, f). Mean values for each $0.5 \mathrm{~km}$ cell (solid curves) and plus/minus RMSE (dashed curves) are shown; $x$ axis indicates the distance from Tallinn Bay (latitude $59.48 \mathrm{~N}$ ) in km along the meridional transect.

$<-40{ }^{\circ} \mathrm{C}$ gives quite similar results to the criterion based on the maximum negative temperature deviation of $-2{ }^{\circ} \mathrm{C}$.

We identified in May-September 2007-2013 altogether 33 upwelling events, approximately half of them (17) near the northern coast and half (16) near the southern coast (Table 2). The number of days with the upwelling near the northern coast was 150 and, near the southern coast, 140. As the total number of days with measurements was 838 , the upwelling occurred in 18 and $17 \%$ of days off the northern and southern coasts, respectively. The maximum negative temperature deviation from the transect mean value was detected in $\mathrm{Au}-$ gust 2010 near the southern coast, when it reached $-7.78^{\circ} \mathrm{C}$. While the maximum temperature deviation characterizes the peak of the upwelling, the introduced cumulative upwelling index also takes into account the extent of the upwelling in space and time. As based on CUI, the largest upwelling events were observed in 2013 - on 15-30 September 2013 off the southern coast $\left(\mathrm{CUI}=-40.2^{\circ} \mathrm{C}\right.$ day) and on $11-31 \mathrm{Au}-$ gust 2013 off the northern coast $\left(\mathrm{CUI}=-39.7{ }^{\circ} \mathrm{C}\right.$ day). The average CUI value of all upwelling events off the northern coast was $-14.5^{\circ} \mathrm{C}$ day and, off the southern coast, $-16.2^{\circ} \mathrm{C}$ day. The sum of CUI values of all detected upwelling events off the northern coast was $-247.0^{\circ} \mathrm{C}$ day and, off the southern coast, $-258.4^{\circ} \mathrm{C}$ day.

The total CUI for all measurement days in 2007-2013 was $-405.3^{\circ} \mathrm{C}$ day for the northern coastal area and $-356.6^{\circ} \mathrm{C}$ day for the southern coastal area. Thus, the negative temperature deviations from the transect mean were more common for the northern coastal sea area, while the upwelling events were more intense in the southern coastal sea area.

The highest number of upwelling events was observed in July -10 events, 5 off the northern coast and 5 off the southern coast - and the lowest in May - 4 events. The sums of CUI values of all events in July and August were $-185.3^{\circ} \mathrm{C}$ day and $-187.9^{\circ} \mathrm{C}$ day, respectively, while it was only $-28.6^{\circ} \mathrm{C}$ day in May. Obviously, the revealed seasonal trend was partly related to the temperature difference between the surface layer and the cold layer beneath the seasonal thermocline, which has its maximum in the Gulf of Finland in July-August (Liblik and Lips, 2011). 

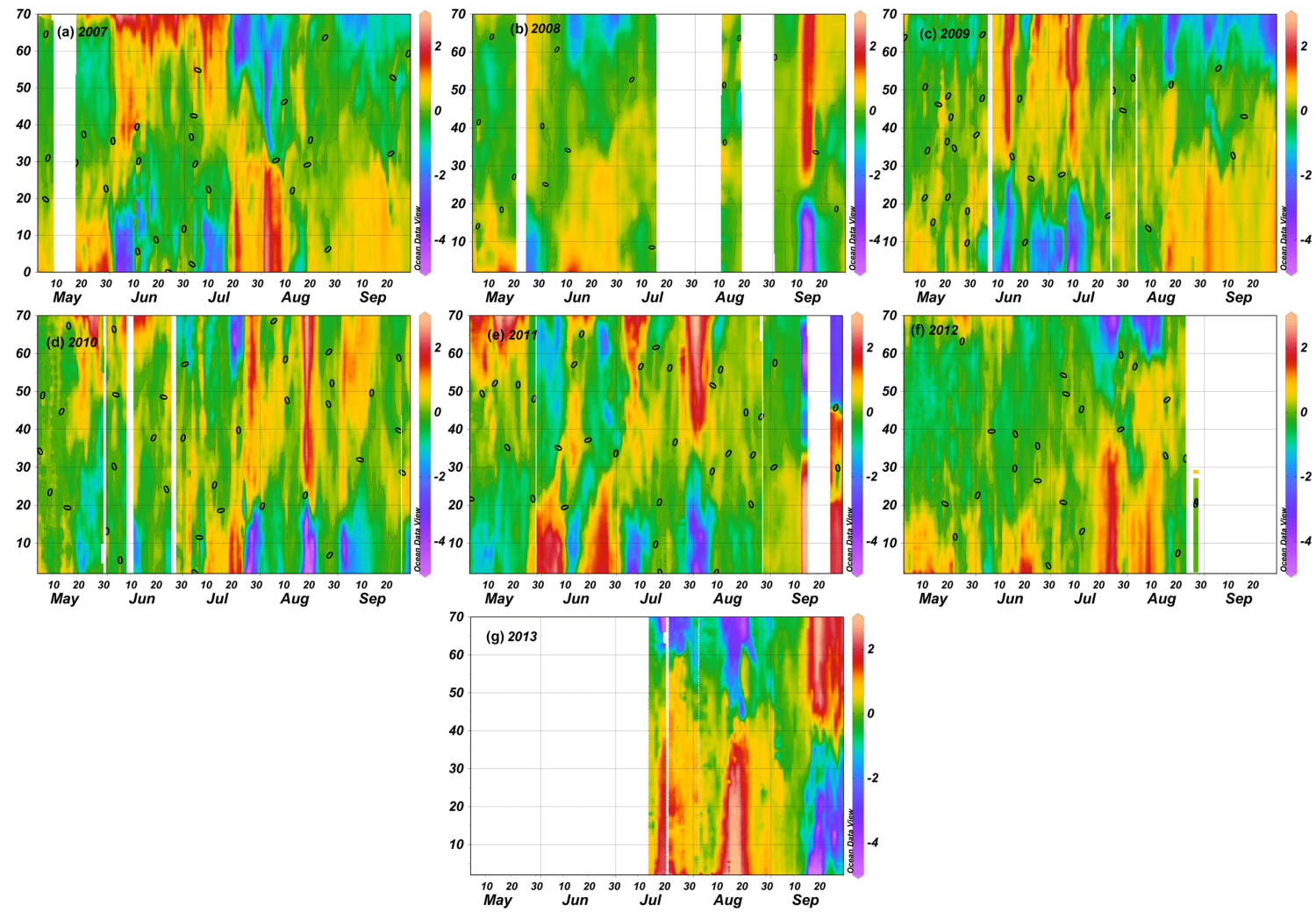

Figure 4. Temporal changes in spatial distributions of temperature deviations (in ${ }^{\circ} \mathrm{C}$ ) from the daily transect mean value between Tallinn and Helsinki from 1 May to 30 September in 2007 (a), 2008 (b), 2009 (c), 2010 (e), 2011 (f), 2012 (g) and 2013 (h); $y$ axis shows the distance from Tallinn Bay (latitude 59.48 N) in kilometers along the meridional transect. Maps are made using Ocean Data View software (Schlitzer, 2015).

\subsection{Upwelling characteristics in relation to wind forcing}

The occurrence of coastal upwelling events in the Gulf of Finland can be related quite well to the variations of the along-gulf wind stress (Fig. 5). The upwelling events appeared after a certain favorable wind pulses with long enough duration and magnitude. In the case of upwelling events off the northern coast, the positive along-gulf wind stress was usually observed a few days before the event and, in the case of upwelling events off the southern coast, the wind stress was negative for a few days (Fig. 5).

The estimated cumulative wind stress for the detected upwelling events varied between 0.31 and $1.37 \mathrm{~N} \mathrm{~m}^{-2}$ day for westerly winds and between -0.09 and $-1.08 \mathrm{~N} \mathrm{~m}^{-2}$ day for easterly winds (Table 2). The cumulative wind stress associated with each upwelling event was calculated based on daily average wind stress values by summing them up from the first day with favorable wind stress (within a period of 1 week before the event) to the last day with favorable wind stress before the end of the event. If only 1 day with opposite wind stress appeared in a sequence in the favorable wind stress series, then the calculation period was not broken. The average value of the cumulative wind stress for an upwelling event off the northern coast was $0.71 \mathrm{~N} \mathrm{~m}^{-2}$ day and, off the southern coast, $-0.44 \mathrm{~N} \mathrm{~m}^{-2}$ day. It suggests that to produce a coastal upwelling event of an equal magnitude the required favorable along-gulf wind stress has to be larger for the upwelling events off the northern coast than for the events off the southern coast. This conclusion is drawn by taking into account the above result that the average upwelling intensity (estimated as CUI) was similar for both coastal areas, with slightly higher values of CUI for the upwelling events off the southern coast. This suggestion is also supported by comparison of relationships between the CUI and cumulative wind stress (CWS) related to the upwelling events near the opposite coasts (Fig. 6). The linear regression lines between the CUI and CWS indicate that at the same CWS values, the upwelling events had higher intensities off the southern coast than off the northern coast. Nevertheless, the results are quite scattered, and the coefficient of determination $\left(r^{2}\right)$ between the CUI and CWS is 0.30 for the southern and 0.19 for the northern upwelling events.

The average along-gulf wind stress for the entire study period from May to September in $2007-2013$ was $0.016 \mathrm{~N} \mathrm{~m}^{-2}$. The seasonal averages had positive values in all studied 

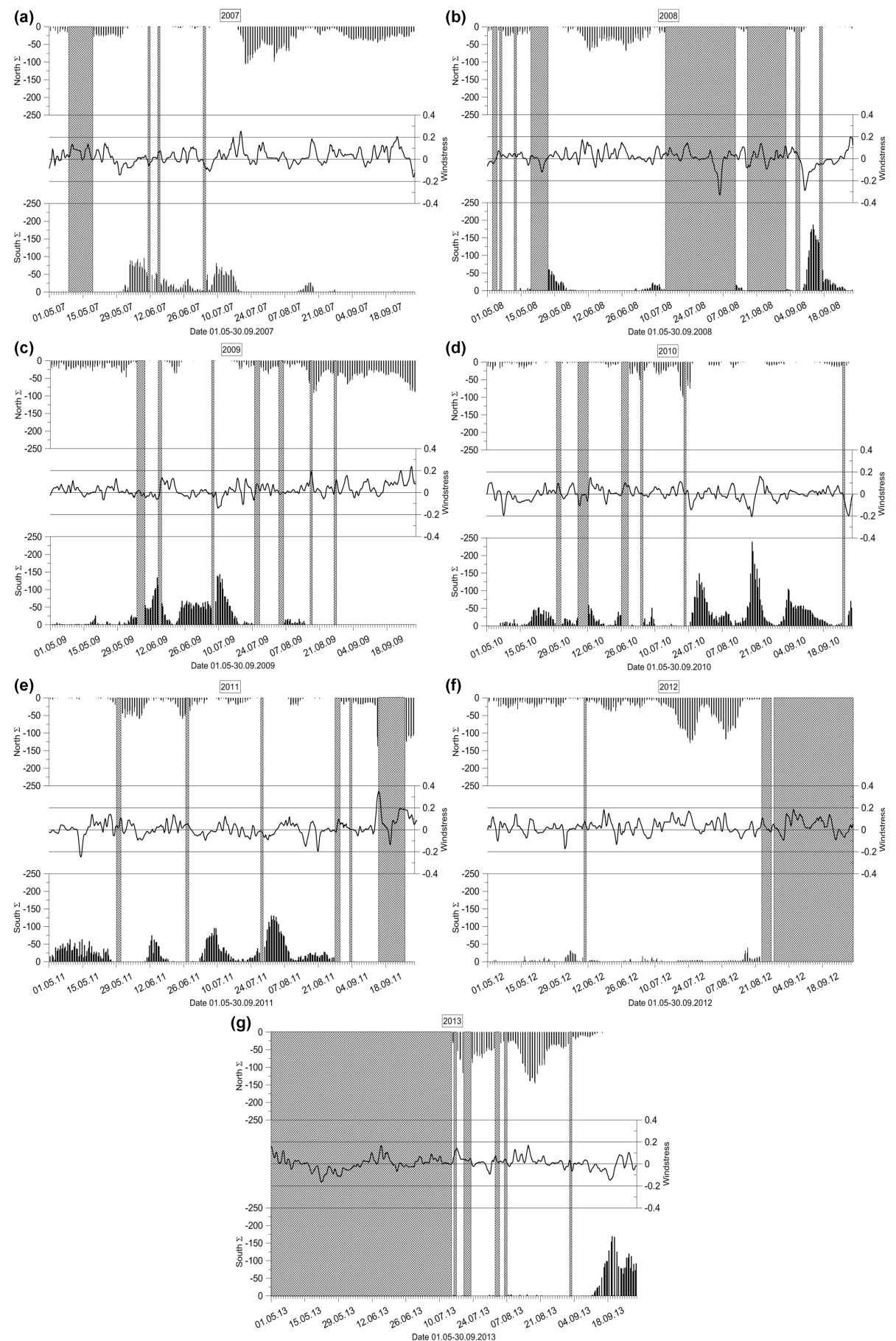

Figure 5. Temporal changes in upwelling index off the northern coast (at the top of each subplot; ${ }^{\circ} \mathrm{C}$ ) and off the southern coast (at the bottom of each subplot; ${ }^{\circ} \mathrm{C}$ ) and along-gulf wind stress (black curve in the middle; $\mathrm{N} \mathrm{m}^{-2}$ ) in May-September 2007 (a), 2008 (b), 2009 (c), 2010 (d), 2011 (e), 2012 (f) and 2013 (g).

years, indicating that the westerly to southwesterly winds prevailed in the region. The average values of wind stress varied between $0.001 \mathrm{~N} \mathrm{~m}^{-2}$ in 2010 and $0.029 \mathrm{~N} \mathrm{~m}^{-2}$ in 2007, 2009 and 2012. In May-September 2010, when five upwelling events occurred off the southern coast and only one event off the northern coast, the average along-gulf wind stress was close to zero, indicating that the cumulative wind forcing was almost equal from both directions. Furthermore, the wind stress averaged over all observed upwelling events in 2007-2013 was $0.015 \mathrm{~N} \mathrm{~m}^{-2}$, which is very close to the 
Table 2. Characteristics of detected upwelling events; dates, coastal area ( $\mathrm{N}$ - off northern coast; $\mathrm{S}$ - off southern coast), type (UF with strong upwelling front; GD - with gradual decrease in temperature), maximum temperature deviation from the transect mean value, cumulative upwelling index calculated for each event and cumulative along-gulf wind stress calculated for upwelling favorable winds before and during the upwelling event.

\begin{tabular}{|c|c|c|c|c|c|c|}
\hline No. & Dates & Coast & Type & $\begin{array}{r}\text { Maximum } \\
\text { temperature } \\
\text { deviation } \\
\left({ }^{\circ} \mathrm{C}\right)\end{array}$ & $\begin{array}{r}\text { Cumulative } \\
\text { upwelling } \\
\text { intensity } \\
\left({ }^{\circ} \mathrm{C} \text { day }\right)\end{array}$ & $\begin{array}{l}\text { Cumulative } \\
\text { wind stress } \\
\left(\mathrm{N} \mathrm{m}^{-2} \text { day) }\right.\end{array}$ \\
\hline 1. & 3-14 June 2007 & $\mathrm{~S}$ & UF & -4.12 & -19.8 & -0.49 \\
\hline 2. & 8-16 July 2007 & $\mathrm{~S}$ & GD & -3.02 & -12.6 & -0.34 \\
\hline 3. & 21-27 July 2007 & $\mathrm{~N}$ & UF & -4.02 & -13.9 & 0.93 \\
\hline 4. & 29 July-8 August 2007 & $\mathrm{~N}$ & GD & -3.64 & -16.5 & 0.38 \\
\hline 5. & $10-17$ September $2007^{1}$ & $\mathrm{~N}$ & GD & -1.97 & -7.5 & 0.75 \\
\hline 6. & 26-28 May $2008^{2}$ & $\mathrm{~S}$ & UF & -2.52 & -3.9 & -0.20 \\
\hline 7. & 11-15 June 2008 & $\mathrm{~N}$ & UF & -2.73 & -7.2 & 0.62 \\
\hline 8. & 27-29 June 2008 & $\mathrm{~N}$ & UF & -2.27 & -6.2 & 0.53 \\
\hline 9. & 10-17 September 2008 & $\mathrm{~S}$ & UF & -5.42 & -23.0 & -1.08 \\
\hline 10. & 9-16 June 2009 & $\mathrm{~S}$ & UF & -4.77 & -14.8 & -0.27 \\
\hline 11. & 24 June-14 July 2009 & $\mathrm{~S}$ & GD & -5.78 & -36.1 & -0.42 \\
\hline 12. & 16-22 August 2009 & $\mathrm{~N}$ & UF & -3.20 & -10.7 & 0.54 \\
\hline 13. & 28 August-9 September 2009 & $\mathrm{~N}$ & UF & -2.74 & -14.1 & 0.56 \\
\hline 14. & $17-30$ September $2009^{3}$ & $\mathrm{~N}$ & UF & -3.09 & -19.3 & 1.28 \\
\hline 15. & 20-24 May 2010 & $\mathrm{~S}$ & GD & -2.21 & -5.1 & -0.56 \\
\hline 16. & $12-13$ June $2010^{4}$ & $\mathrm{~S}$ & UF & -2.60 & -2.3 & -0.19 \\
\hline 17. & 20-24 July 2010 & $\mathrm{~N}$ & UF & -4.70 & -9.3 & 0.31 \\
\hline 18. & 26 July-1 August 2010 & $\mathrm{~S}$ & UF & -6.19 & -15.7 & -0.34 \\
\hline 19. & 17-23 August 2010 & $\mathrm{~S}$ & UF & -7.78 & -20.8 & -0.66 \\
\hline 20. & 2-12 September 2010 & $\mathrm{~S}$ & GD & -5.27 & -16.0 & -0.25 \\
\hline 21. & $4-12$ May $2011^{5}$ & $\mathrm{~S}$ & GD & -2.22 & -9.3 & -0.09 \\
\hline 22 & 31 May-8 June 2011 & $\mathrm{~N}$ & UF & -2.32 & -10.3 & 0.60 \\
\hline 23. & 11-15 June 2011 & $\mathrm{~S}$ & UF & -3.12 & -6.0 & -0.38 \\
\hline 24. & 24-27 June 2011 & $\mathrm{~N}$ & UF & -2.40 & -4.8 & 0.41 \\
\hline 25. & 5-10 July 2011 & $\mathrm{~S}$ & GD & -5.05 & -10.6 & -0.38 \\
\hline 26. & 29 July-7 August 2011 & $\mathrm{~S}$ & GD & -4.69 & -22.2 & -0.62 \\
\hline 27. & 14 September $2011^{6}$ & $\mathrm{~N}$ & UF & -4.90 & -3.1 & 0.47 \\
\hline 28. & 26-30 September $2011^{7}$ & $\mathrm{~N}$ & UF & -3.27 & -13.8 & 1.26 \\
\hline 29. & $18-27$ July $2012^{8}$ & $\mathrm{~N}$ & GD & -4.55 & -22.4 & 1.37 \\
\hline 30. & 2-13 August 2012 & $\mathrm{~N}$ & UF & -4.17 & -22.2 & 0.58 \\
\hline 31. & 17 July-1 August $2013^{9}$ & $\mathrm{~N}$ & UF & -6.15 & -26.0 & 0.63 \\
\hline 32. & 11-31 August 2013 & $\mathrm{~N}$ & GD & -5.03 & -39.7 & 0.92 \\
\hline 33. & 15-30 September 2013 & $\mathrm{~S}$ & UF & -7.34 & -40.2 & -0.71 \\
\hline
\end{tabular}

\footnotetext{
1 Temperature deviation was less than $-2{ }^{\circ} \mathrm{C}$ during the event on $10-17$ September $2007 ;{ }^{2}$ data absent before 26 May 2008 for more than 1 day; ${ }^{3}$ data analyzed until 30 September 2009 (upwelling event continued); ${ }^{4}$ data absent before 12 June 2010 for more than 1 day; ${ }^{5}$ early spring with possible contribution of difference in surface water warming; ${ }^{6}$ no data available after 14 September 2011 ; 7 no data available before 26 September 2011 , wind data missing on 24-26 September 2011 ; $^{8}$ wind data on $14-15$ July 2012 not available; ${ }^{9}$ ferrybox data on 20-21 July 2013 not available.
}

average wind stress over the entire study period. This estimate was obtained based on the mean length of upwelling events of 8.8 days and mean cumulative wind stress values of 0.71 and $-0.44 \mathrm{~N} \mathrm{~m}^{-2}$ day off the northern and southern coasts, respectively. It can be concluded that the difference between the wind impulses needed for the generation of upwelling events with similar intensity near the opposite coasts is comparable to the average along-gulf wind stress in the region.

Usually, the upwelling events occurred 1 or a few days after the start of the favorable wind pulse, and the maximum of upwelling intensity was reached 1 or a few days after the maximum wind stress (Fig. 5). We made an attempt to identify characteristic spatial temperature and salinity distributions in the surface layer from coast to coast at times 


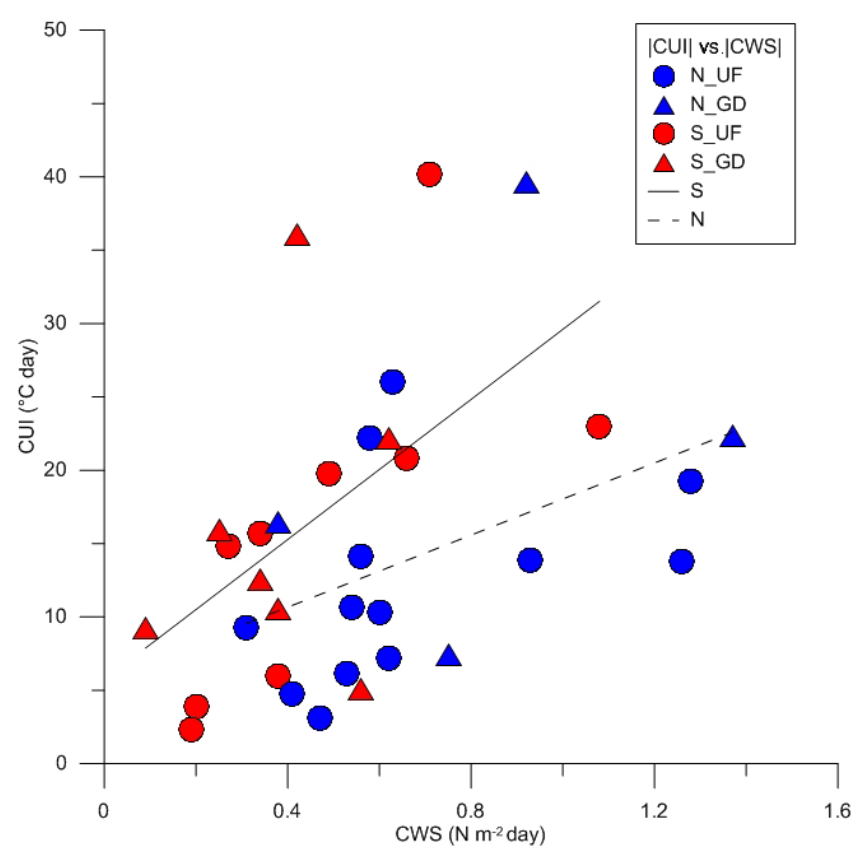

Figure 6. The relationship between the cumulative upwelling index (CUI) and cumulative along-gulf wind stress (CWS) based on 33 detected upwelling events in May-September 2007-2013. Red symbols indicate the events off the southern coast and blue symbols the events off the northern coast; circles correspond to the events with a pronounced upwelling front (N_UF and C_UF) and triangles the events with a gradual decrease in temperature towards the coast (N_GD and S_GD). The linear regression lines for southern (solid line) and northern upwelling events (dashed line) are shown.

of the maximum intensity of upwelling events. Surprisingly, the results did not differ significantly between the northern and southern coasts - two characteristic shapes of upwelling events in the temperature distribution were identified for both coastal areas.

Mostly the upwelling events were characterized by a sharp and very intense temperature front between the upwelling waters and the rest of the transect (red curves in Fig. 7a and c). The sharp upwelling fronts are usually associated with strong along-front jet currents, for instance, as measured by Suursaar and Aps (2007) in the Gulf of Finland in summer 2006. Typical for such events were an almost uniform temperature outside the upwelling area and the temperature minimum (maximum temperature deviation) close to the upwelling front. The other distribution pattern (dark blue curves in Fig. 7a and c) exposed a gradual decrease in temperature towards the upwelling waters. Typical for the latter events were the irregularities in temperature distribution with a characteristic scale of a few kilometers and the temperature minimum (maximum temperature deviation) in the cell closest to the shore. In some cases, e.g., the event near the northern coast with maximum intensity on 18 August 2013 (dark blue solid curve in Fig. 7a), the observed temperature deviations were as large as during the upwelling events with strong temperature fronts. There was also a third type of temperature distribution when the upwelling waters were not attached to the shore (red dotted curve in Fig. 7a), at least according to the measurements along the ferry route. All these types of upwelling events are well recognized on the maps of temporal changes in temperature and temperature deviation along the Tallinn-Helsinki ferry route (Figs. 2 and 4).

The spatial distribution of salinity in the surface layer from coast to coast drastically differed between the upwelling events near the northern coast and the events near the southern coast (Fig. 7b and d). In the latter case, both the salinity difference across the gulf and the spatial variability at scales of a few kilometers to $10 \mathrm{~km}$ were much larger than in the former case. It is also interesting that in the case of southern upwelling events, the salinity minimum along the transect can be situated either very close to the upwelling front (e.g., on 28 July 2010) or near the northern coast (e.g., 8 July 2011). Although such diverse patterns are partly related to the history of water movements in the gulf, the salinity minimum (at least local minimum) close to the upwelling front might be caused by the westward current jet along the front as also revealed by model experiments (Laanemets et al., 2011). The salinity distribution across the gulf associated with the northern upwelling events is very uniform, with some variability at scales of a few kilometers to $10 \mathrm{~km}$, which have the amplitude several times less than spatial salinity variations associated with the southern upwelling events.

\section{Discussion}

Several studies have shown how the Ferrybox measurements are successfully used for different applications, such as for monitoring of coastal waters in combination with remote sensing (Petersen et al., 2008), estimating carbon fluxes and primary productivity (Schneider et al., 2014) and detecting cyanobacterial blooms (Seppälä et al., 2007). However, not enough attention is paid to the Ferrybox systems, especially to the question of how the results are affected by the used technical solutions (like water intake depth and construction, piping). Furthermore, the particularities of geographical location as well as the ferry route and schedule often determine the most suitable applications and requirements for the data treatment. A good example of taking advantage of the geographical location and ferry route is demonstrated by Buijsman and Ridderinkhof (2007), who estimated the water and suspended matter exchange between the Wadden Sea and the North Sea using data collected along the Den Helder-Texel ferry route.

The ferry route between Tallinn and Helsinki across the elongated Gulf of Finland and the schedule consisting of two cruises a day and a short $1.5 \mathrm{~h}$ stay in Helsinki made it possible to introduce a procedure for correction of coordinates of measurement points and an additional quality check 
(a) Upwelling off northern coast, temperature

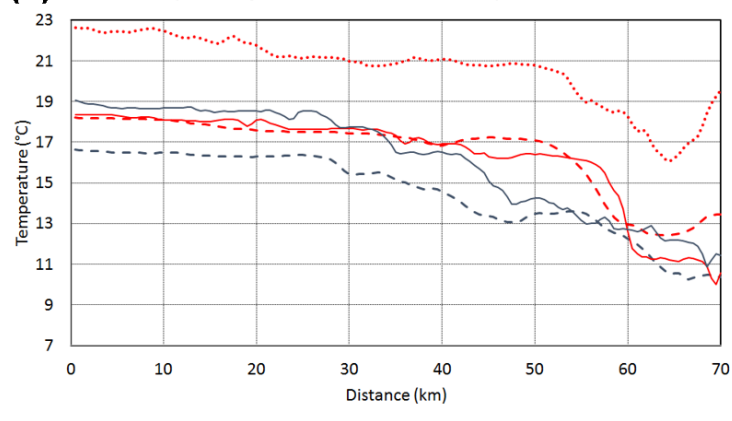

…21.07.2010 - - 24.07.2012 - -08.08.2012 - 19.07.2013 - 18.08 .2013

(c) Upwelling off southern coast, temperature

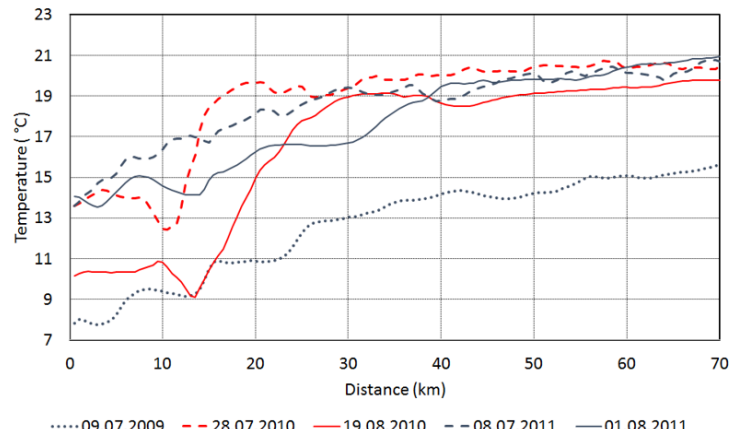

(b) Upwelling off northern coast, salinity

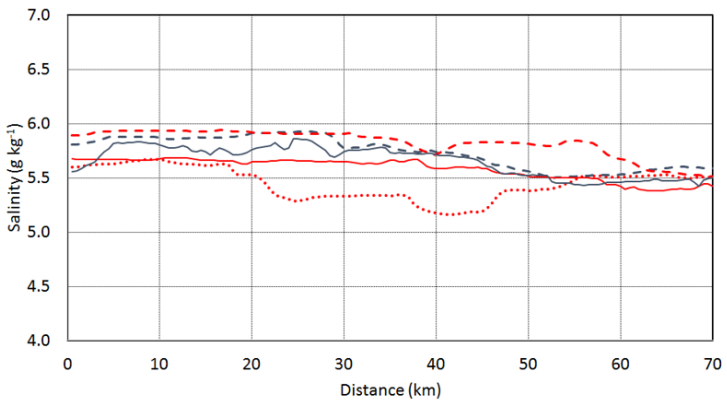

.....21.07.2010 - - 24.07.2012 - -08.08.2012 - 19.07.2013 - 18.08.2013

(d) Upwelling off southern coast, salinity

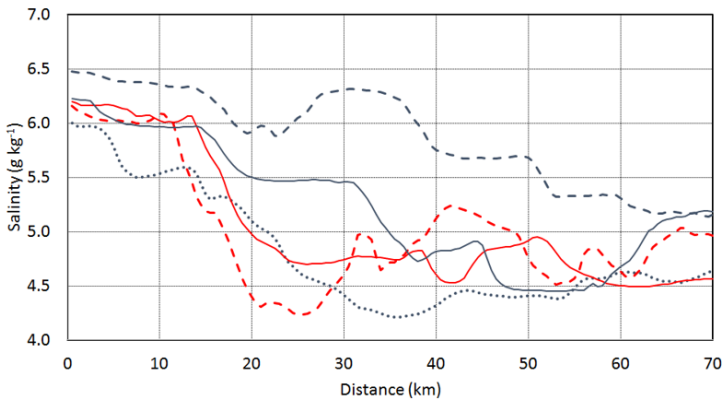

Figure 7. Characteristic distributions of temperature and salinity along the Tallinn-Helsinki ferry route with coastal upwelling events off the northern coast $(\mathbf{a}, \mathbf{b})$ and off the southern coast $(\mathbf{c}, \mathbf{d}) ; x$ axis shows the distance from Tallinn Bay (latitude $59.48 \mathrm{~N}$ ) in $\mathrm{km}$ along the meridional transect.

routine for the collected data. The correlation between the data from the two crossings on the same day must be sufficiently high; if not, the data are marked as suspicious. We found that the highest correlation between the two data sets is achieved when the data points are shifted by $3-4 \mathrm{~min}$, depending on the intake installation and the ferry. This analysis also demonstrates the confidence of the applied Ferrybox system even though the water is taken in through a relatively large sea chest. Furthermore, the ferry route across the relatively narrow gulf from coast to coast is very convenient to collect data on the offshore extension and intensity of coastal upwelling events.

Various methods have been applied to reveal characteristic features of coastal upwelling events in the Baltic Sea based on data mainly from remote sensing and numerical models. Data of high-resolution long-term Ferrybox measurements have not been analyzed with this aim until now. A certain temperature isoline as the boundary of the upwelling area was used by Uiboupin and Laanemets (2009) and a temperature deviation $\left(2{ }^{\circ} \mathrm{C}\right)$ from the mean temperature along zonal transects was employed by Lehmann et al. (2012). The latter method is similar to the approach applied in the present study, but we argue that the analysis of temperature deviations along meridional transects is more appropriate in the Gulf of Finland. This conclusion is justified by the fact that, on average, the north-south temperature gradient is negligi- ble in the gulf (see Fig. 3a), while the west-east temperature gradient could exist between the shallower and narrower Gulf of Finland and the deeper and wider northern Baltic proper due to differential warming and cooling.

Nevertheless, it is interesting that our results on upwelling frequencies of about $17-18 \%$ near the northern and southern coasts are very close to the results of Lehmann et al. (2012) if their results based on remote sensing data were considered. They concluded that upwelling events were present more than $15 \%$ of the time near the northern coast and about $15 \%$ of the time near the southern coast. At the same time, the estimates of corresponding upwelling frequencies based on numerical experiments differ from the values obtained from the remote sensing data and the results of the present study. Based on model results, the northern coastal area has been suggested as the main upwelling area in the Gulf of Finland, with the upwelling occurrence up to $30 \%$ of the time (Lehmann et al., 2012; Myrberg and Andrejev, 2003), while near the southern coast downwelling should prevail (Myrberg and Andrejev, 2003).

Analysis of wind data has also suggested that the coastal upwelling events should occur more often along the northern coast than along the southern coast of the Gulf of Finland (Lehmann et al., 2012; Uiboupin and Laanemets, 2009). The data set consisting of 838 days of measurements from coast to coast used in the present analysis has revealed that, on 

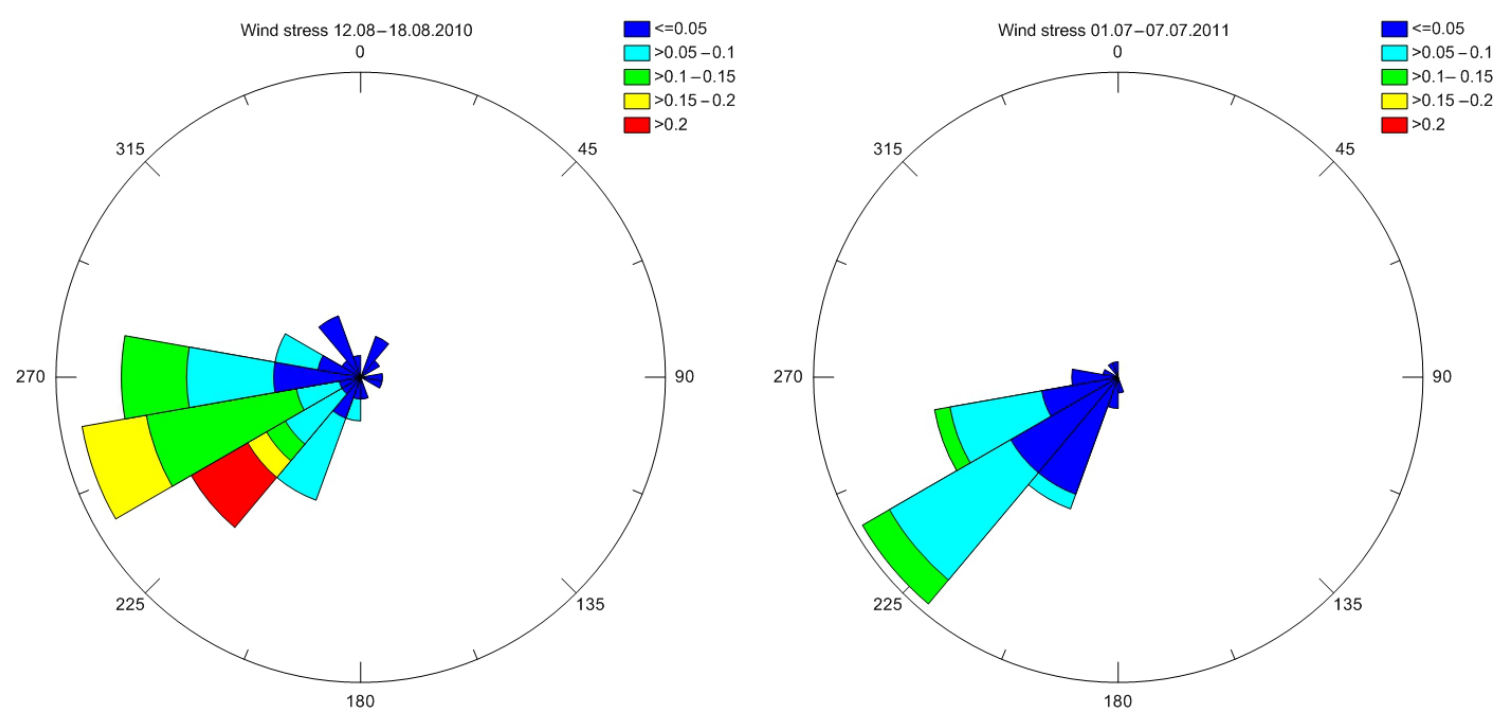

Figure 8. Polar histogram of wind stress vectors $\left(\mathrm{N} \mathrm{m}^{-2}\right)$ based on the wind data from a weekly period before the peak of upwelling events off the Estonian coast on 17-23 August 2010 (left panel) and 5-11 July 2011 (right panel).

average, the frequency of upwelling events and their intensity are similar near the northern and southern coasts of the gulf, although the wind data from the same period suggest prevalence of upwelling events off the northern coast. Partly, this outcome can be explained by the higher position of the thermocline, steeper bottom slope and greater depths in the southern part of the gulf as suggested by some earlier studies (e.g., Väli et al., 2011; Laanemets et al. 2009). Based on a simple theory of upwelling dynamics linking the position of the onshore return flow with the bottom slope and stratification (Lentz and Chapman, 2004), Laanemets et al. (2009) estimated that the onshore return flow should occur in the near-bottom layer for both northern and southern upwelling events in the Gulf of Finland. Due to the steeper slope and greater depths, the upwelling outcome in the vertical transport of cold and nutrient rich waters could be more intense in the southern gulf (Väli et al., 2011; Laanemets et al., 2009).

An additional explanation could be suggested when taking into account the estuarine character of the Gulf of Finland the basin has free water exchange with the Baltic proper in the west, while it is closed in the east where the main freshwater source is located. First, this basin configuration and the prevalence of southwesterly winds together with the Coriolis force cause a general cyclonic circulation in the surface layer of the gulf (Alenius et al., 1998). Such circulation, in accordance with the geostrophic balance, results in a higher sea level and deeper thermocline in the northern part of the gulf (e.g., see Andrejev et al., 2004). A similar transverse thermohaline and residual flow structure has been noted by Thomson et al. (2007) in the Juan de Fuca Strait. Liblik and Lips (2016) also concluded that the thermocline is on average at a deeper depth in the northern Gulf of Finland based on their analysis of the data from 35 cross-gulf CTD (conductiv- ity, temperature and depth) surveys conducted in 2006-2013. Thus, the wind impulse needed for the initiation of a coastal upwelling event near the southern coast can have a smaller magnitude. This suggestion is supported by the comparison of the lowest cumulative wind stress values, which have initiated upwelling events in 2007-2013 near the two coasts. The lowest CWS value related to an upwelling event along the northern coast is larger than the CWS values for five upwelling events along the southern coast (see Fig. 6).

Secondly, we suggest that for a stronger wind impulse during a longer period, the estuarine character of the basin has a significant influence on the outcome. The strong southwesterly (up-estuary) winds counteract the estuarine circulation and cause an inflow (convergence) in the surface layer (Elken et al., 2003; Lips et al., 2008b), and thus, a downward movement of the thermocline in the gulf as a whole. In contrast, the down-estuary winds intensify the outflow (cause divergence) in the surface layer, and thus, a general upward movement of the thermocline in the gulf. Consequently, the up-estuary southwesterly winds, on the one hand, cause upwelling along the northern coast, but on the other hand downwelling in the gulf as a whole that could weaken the outcome. In the case of the down-estuary easterly to northeasterly winds, a general upward movement of the thermocline in the gulf supports the coastal upwelling along the southern coast. Such a response of the water movements to the forcing could be an explanation why, in general, the cumulative upwelling indices (presented in Fig. 6) increase faster with the strengthening of the favorable wind stress (CWS in Fig. 6) for the southern upwelling events than for the northern upwelling events.

The average cross-gulf distributions of temperature and salinity were described based on the 7-year data set of horizontal profiles. On average, the surface layer temperature 
did not have any horizontal gradient, while the surface layer salinity was higher in the southern part than in the northern part of the gulf. The result that the surface water with the lowest salinity was on average at about $20 \mathrm{~km}$ from the northern coast supports the suggested general circulation scheme in the Gulf of Finland (e.g., Andrejev et al., 2004). At the same time, if the wind forcing favorable for upwelling events near the southern coast prevailed (as was observed in summer 2010), the low salinity water appeared in the southern part of the open gulf, close to the upwelling front. This phenomenon was also observed during an intense upwelling event in August 2006 (Lips et al., 2009); it was modeled by Laanemets et al. (2011) and noted by Liblik and Lips (2016) based on an analysis of CTD data from surveys across the gulf in 20062013.

The most intense upwelling events regarding temperature deviations were observed near the southern coast, as was also found by Uiboupin and Laanemets (2009, 2015). However, we did not identify clear differences in the temperature distribution patterns between the upwelling events off the two coasts. Instead, near both coasts, the classical distributions with a sharp temperature front as well as the distribution characterized by a gradual decrease in temperature towards the coast have been observed. We suggest that the upwelling events with the gradual temperature decrease could be associated with the development of upwelling filaments, which occurred under certain conditions and stayed in our measurement window.

In the case of the upwelling events along the southern coast, the wind speed was on average higher before the events with the sharp temperature front (see Fig. 6 and Table 2). For instance, the polar histograms of wind stress vectors shown in Fig. 8 are very similar except for the distribution of wind stress magnitudes. The period before the culmination of the upwelling event with the sharp temperature front observed on 19 August 2010 had a large share of wind stress values $>0.15 \mathrm{~N} \mathrm{~m}^{-2}$. Nevertheless, the two prominent upwelling events along the northern coast - the most intense event (on 11-31 August 2013) and the event corresponding to the largest cumulative wind stress (on 18-27 July 2012) were both characterized by the gradual decrease in temperature towards the coast (Fig. 6).

The filaments of upwelled waters are characteristic features of the upwelling events in the Gulf of Finland (Uiboupin and Laanemets, 2009). Zhurbas et al. (2008) have shown based on a numerical experiment that the cold/warm water squirts and filaments could develop after the weakening of the upwelling favorable winds. Similarly, the squirts and filaments could develop if the wind forcing is strong enough to initiate an upwelling event but not as strong as needed to retain the mesoscale frontal dynamics. In the case of the southern upwelling events, it explains why upwelling events with the gradual decrease in temperature mostly occurred when the wind forcing was on average weaker.
As shown by Zhurbas et al. (2006), the baroclinic instability of the upwelling jet is expected to occur when the bottom slope is smaller than the isopycnal slope. Thus, for the strong upwelling events, the filaments might appear with a higher probability in the case of northern upwelling events since the bottom slope is about 2 times shallower in the northern gulf than in the southern gulf (Uiboupin and Laanemets, 2009). The prevailing westerly to southwesterly winds, which cause an inflow in the upper layer and a compensating outflow in the deeper layers (Elken et al., 2003; Liblik and Lips, 2012), could lead to the deepening of the seasonal thermocline in the gulf in 2012 and 2013. The two very intense upwelling events with the gradual temperature decrease were observed in these summers along the northern coast. Since the upwelling dynamics is dependent on the vertical structure of the water column before the event (e.g., Lentz and Chapman, 2004), these suggestions have to be studied further in the future by combining Ferrybox data (restricted to the surface layer and single transect) with the remote sensing and water column data.

\section{Conclusions}

We showed that Ferrybox data from the Tallinn-Helsinki ferry route could be successfully employed to describe the characteristics of coastal upwelling events in the Gulf of Finland. An advantage of the geographical location of the ferry route across the relatively narrow gulf and the schedule consisting of two crossings a day allowed one to control the quality of the data and introduce the upwelling index based on the data from a single crossing and the cumulative upwelling index. In total, 33 coastal upwelling events were identified in May-September 2007-2013. It is shown that the upwelling occurrences of 18 and $17 \%$ of days, as well as intensities of upwelling events, are similar near the northern and southern coasts. The most intense events occur in July-August, most probably because of the warmest surface layer (strongest thermocline) during those months. It is shown that the wind impulse needed to generate upwelling events of similar intensity differs between the two coastal areas. We suggest that the general thermohaline structure (adapted to the prevailing forcing) and the estuarine character of the basin are reasons for the found different outcome. The thermohaline structure of the Gulf of Finland is characterized by a deeper position of the thermocline in the northern gulf; thus, the upwelling initiation requires a stronger southwesterly wind impulse to cause upwelling along the northern coast as compared to a weaker northeasterly impulse to cause upwelling along the southern coast. Furthermore, the estuarine character of the basin leads to the weakening of the upwelling created by the westerly (up-estuary) winds and strengthening of the upwelling created by the easterly (down-estuary) winds. Two types of upwelling events were identified - one characterized by a strong temperature (upwelling) front and the other revealing grad- 
ual decrease in temperature from the open sea to the coastal area, with maximum temperature deviation very close to the shore. We suggest that the spatial variations in temperature with scales of a few kilometers, which were characteristic of the upwelling events with the gradual temperature decrease, could be signs of the meso- and sub-mesoscale features (filaments and squirts) associated with the upwelling dynamics.

\section{Data availability}

Underlying data (as raw data which have passed automatic quality check) are available via EMODnet Physics portal http://www.emodnet-physics.eu/Map/platinfo/ PIROOSDownload.aspx?PlatformID=8440.

Acknowledgements. We are grateful to Tallink (Estonia) for the possibility to conduct the measurements on board the ferries. We thank our colleagues, especially Inga Lips and Fred Buschmann, for their help in maintaining the Ferrybox system, and Taavi Liblik for his suggestions regarding data processing. This work was supported by institutional research funding IUT19-6 of the Estonian Ministry of Education and Research and by EU Regional Development Foundation, Environmental Conservation and Environmental Technology R\&D Programme project VeeOBS (3.2.0802.11-0043).

Edited by: M. Hoppema

\section{References}

Alenius, P., Myrberg, K., and Nekrasov, A.: The physical oceanography of the Gulf of Finland: a review, Boreal Environ. Res., 3, 97-125 1998.

Andrejev, O., Myrberg, K., Alenius, P., and Lundberg, P. A.: Mean circulation and water exchange in the Gulf of Finland - a study based on three-dimensional modeling, Boreal Environ. Res., 9, 1-16, 2004.

Buijsman, M. C. and Ridderinkhof, H.: Long-term ferry-ADCP observations of tidal currents in the Marsdiep inlet, J. Sea Res., 57, 237-256, 2007.

Elken, J., Raudsepp, U., and Lips, U.: On the estuarine transport reversal in deep layers of the Gulf of Finland, J. Sea Res. 49, 267-274, 2003.

Feistel, R., Weinreben, S., Wolf, H., Seitz, S., Spitzer, P., Adel, B., Nausch, G., Schneider, B., and Wright, D. G.: Density and Absolute Salinity of the Baltic Sea 2006-2009, Ocean Sci., 6, 3-24, doi:10.5194/os-6-3-2010, 2010.

Haapala, J.: Upwelling and its influence on nutrient concentration in the coastal area of the Hanko Peninsula, entrance of the Gulf of Finland, Est. Coast. Shelf Sci., 38, 507-521, 1994.

Hardman-Mountford, N. J., Moore, G., Bakker, D. C. E., Watson, A. J., Schuster, U., Barciela, R., Hines, A., Moncoiffé, G., Brown, J., Dye, S., Blackford, J., Somerfield, P. J., Holt, J., Hydes, D. J., and Aiken, J.: An operational monitoring system to provide indicators of $\mathrm{CO}_{2}$-related variables in the ocean, ICES J. Mar. Sci., 65, 1498-15032008.
Keevallik, S. and Soomere, T.: Towards quantifying variations in wind parameters across the Gulf of Finland, Est. J. Earth Sci., 59, 288-297, 2010.

Kononen, K., Kuparinen, J., Mäkela, K., Laanemets, J., Pavelson, J., and Nõmmann, S.: Initiation of cyanobacterial blooms in a frontal region at the entrance to the Gulf of Finland, Baltic Sea, Limnol. Oceanogr., 41, 98-112, 1996.

Laanemets, J., Zhurbas, V., Elken, J., and Vahtera, E.: Dependence of upwelling-mediated nutrient transport on wind forcing, bottom topography and stratification in the Gulf of Finland: model experiments, Boreal Environ. Res., 14, 213-225, 2009.

Laanemets, J., Väli, G., Zhurbas, V., Elken, J., Lips, I., and Lips, U.: Simulation of mesoscale structures and nutrient transport during summer upwelling events in the Gulf of Finland in 2006, Boreal Environ. Res., 16, 15-26, 2011.

Large, W. G. and Pond, S.: Open ocean momentum flux measurements in moderate to strong winds, J. Phys. Oceanogr., 11, 324336, 1981.

Lehmann, A., Myrberg, K., and Höflich, K.: A statistical approach to coastal upwelling based on the analysis of satellite data for 1990-2009, Oceanologia, 54, 369-393, 2012.

Lentz, S. J. and Chapman, D. C.: The importance of nonlinear crossshelf momentum flux during wind-driven coastal upwelling, J. Phys. Oceanogr., 34, 2444-2457, 2004.

Liblik, T. and Lips, U.: Characteristics and variability of the vertical thermohaline structure in the Gulf of Finland in summer, Boreal Environ. Res., 16, 73-83, 2011.

Liblik, T. and Lips, U.: Variability of synoptic-scale quasistationary thermohaline stratification patterns in the Gulf of Finland in summer 2009, Ocean Sci., 8, 603-614, doi:10.5194/os-8603-2012, 2012.

Liblik, T. and Lips, U.: Variability of pycnoclines in a three-layer, large estuary: the Gulf of Finland, Boreal Environ. Res., in press, 2016.

Lips, I. and Lips, U.: Abiotic factors influencing cyanobacterial bloom development in the Gulf of Finland (Baltic Sea), Hydrobiologia, 614, 133-140, 2008.

Lips, U., Lips, I., Kikas, V., and Kuvaldina, N.: Ferrybox measurements: a tool to study meso-scale processes in the Gulf of Finland (Baltic Sea), US/EU-Baltic Symposium, Tallinn, 27-29 May 2008, IEEE Conference Proceedings, 1-6, 2008a.

Lips, U., Lips, I., Liblik, T., and Elken, J.: Estuarine transport versus vertical movement and mixing of water masses in the Gulf of Finland (Baltic Sea), US/EU-Baltic Symposium, Tallinn, 27-29 May 2008, IEEE Conference Proceedings, 1-8, 2008 b.

Lips, I., Lips, U., and Liblik, T.: Consequences of coastal upwelling events on physical and chemical patterns in the central Gulf of Finland (Baltic Sea), Cont. Shelf Res. 29, 1836-1847 2009.

Männik, A. and Merilain, M.: Verification of different precipitation forecasts during extended winter-season in Estonia, HIRLAM Newsletter, 52, 65-70, 2007.

Myrberg, K., Lehmann, A., Raudsepp, U., Szymelfenig, M., Lips, I., Lips, U., Matciak, M., Kowalewski, M., Krezel, A., Burska, D., Szymanek, L., Ameryk, A., Bielecka, L., Bradtke, K., Galkowska, A., Gromisz, S., Jedrasik, J., Kaluzny, M., Kozlowski, L., Krajewska-Soltys, A., Oldakowski, B., Ostrowski, M., Zalewski, M., Andrejev, O., Suomi, I., Zhurbas, V., Kauppinen, O.-K., Soosaar, E., Laanemets, J., Uiboupin, R., Talpsepp, L., Golenko, M., Golenko, N., and Vahtera, E.: Upwelling events, 
coastal offshore exchange, links to biogeochemical processes Highlights from the Baltic Sea Science Congress at Rostock University, Germany, 19-22 March 2007, Oceanologia, 50, 95-113, 2008.

Myrberg, K. and Andrejev, O.: Main upwelling regions in the Baltic Sea - a statistical analysis based on three-dimensional modeling, Boreal Environ. Res., 8, 97-112, 2003.

Paerl, H. W., Rossignol, K. L., Guajardo, R., Hall, N. S., Joyner, A., Peierls, B. L., and Ramus, J. S.: FerryMon: Ferry-Based Monitoring and Assessment of Human and Climatically Driven Environmental Change in the Albemarle-Pamlico Sound System, Environ. Sci. Technol., 43, 7609-7613, 2009.

Pavelson, J., Laanemets, J., Kononen, K., and Nõmman, S.: Quasipermanent density front at the entrance to the Gulf of Finland: Response to wind forcing, Cont. Shelf Res., 17, 253-265, 1997.

Petersen, W.: FerryBox systems: State-of-the-art in Europe and future development, J. Marine Syst., 140, 4-12, 2014.

Petersen W., Wehde, H., Krasemann, H., Colijn, F., and Schroeder, F.: FerryBox and MERIS - Assessment of coastal and shelf sea ecosystems by combining in situ and remotely sensed data, Est. Coast. Shelf Sci., 77, 296-307, 2008.

Rantajärvi, E. (Ed.): Alg@line in 2003: 10 years of innovative plankton monitoring and research and operational information service in the Baltic Sea, MERI - Report Series of the Finnish Institute of Marine Research, No. 48, 1-36, 2003.

Schlitzer, R.: Ocean Data View, https://odv.awi.de/, 2015.

Schneider, B., Gülzow, W., Sadkowiak, B., and Rehder, G.: Detecting sinks and sources of $\mathrm{CO}_{2}$ and $\mathrm{CH}_{4}$ by ferrybox-based measurements in the Baltic Sea: Three case studies, J. Marine Syst., 140, 13-25, 2014.

Seppälä, J., Ylöstalo, P., Kaitala, S., Hällfors, S., Raateoja, P., and Maunula, P.: Ship-of-opportunity based phycocyanin fluorescence monitoring of the filamentous cyanobacteria bloom dynamics in the Baltic Sea, Est. Coast. Shelf Sci., 73, 489-500, 2007.

Suursaar, Ü. and Aps, R.: Spatio-temporal variations in hydrophysical and -chemical parameters during a major upwelling event off the southern coast of the Gulf of Finland in summer 2006, Oceanologia, 49, 209-228, 2007.
Talpsepp, L., Nõges, T., Raid, T., and Kõuts, T.: Hydrophysical and hydrobiological processes in the Gulf of Finland in summer 1987 - characterization and relationship, Cont. Shelf Res., 14, 749763, 1994.

Thomson, R. E., Mihaly, S. F., and Kulikov E. A.: Estuarine versus transient flow regimes in Juan de Fuca Strait, J. Geophys. Res. 112, C09022, doi:10.1029/2006JC003925, 2007.

Uiboupin, R. and Laanemets, J.: Upwelling characteristics derived from satellite sea surface temperature data in the Gulf of Finland, Baltic Sea, Boreal Environ. Res., 14, 297-304, 2009.

Uiboupin, R. and Laanemets, J.: Upwelling parameters from biascorrected composite satellite SST maps in the Gulf of Finland (Baltic Sea), IEEE Geosci. Remote Sens. Lett., 12, 592-596, 2015.

Vahtera, E., Laanemets, J., Pavelson, J., Huttunen, M., and Kononen, K.: Effect of upwelling on the pelagic environment and bloom-forming cyanobacteria in the Western Gulf of Finland, Baltic Sea, J. Marine Syst., 58, 67-82, 2005.

Väli, G.: Numerical experiments on matter transport in the Baltic Sea. PhD thesis, Tallinn Technical University Press, 2011.

Väli, G., Zhurbas, V., Laanemets, J., and Elken, J.: Simulation of nutrient transport from different depths during an upwelling event in the Gulf of Finland, Oceanologia, 53, 431-448, 2011.

Zhurbas, V., Laanemets, J., and Vahtera, E.: Modeling of the mesoscale structure of coupled upwelling/downwelling events and the related inputs of nutrients to the upper mixed layer in the Gulf of Finland, Baltic Sea, J. Geophys. Res., 113, C05004, doi:10.1029/2007JC004280, 2008.

Zhurbas, V. M., Oh, I. S., and Park, T.: Formation and decay of a longshore baroclinic jet associated with transient coastal upwelling and downwelling: a numerical study with application to the Baltic Sea, J. Geophys. Res., 111, C04014, doi:10.1029/2005JC003079, 2006. 